\title{
GAMBARAN KECEMASAN DALAM MENGHADAPI UJIAN OSCE UKMPPD PADA MAHASISWA FIRST TAKER PENDIDIKAN PROFESI DOKTER UNIVERSITAS MALAHAYATI BATCH NOVEMBER 2019
}

\author{
Festy Ladyani Mustofa ${ }^{1}$, Jordy Oktobiannobel ${ }^{2}$, Sulesa ${ }^{3}$
}

${ }^{1}$ Departemen Gizi Medik Fakultas Kedokteran Universitas Malahayati

${ }^{2}$ Departemen Farmakologi Fakultas Kedokteran Universitas Malahayati

${ }^{3}$ Program Studi Kedokteran Fakultas Kedokteran Universitas Malahayati

[email korespondensi: sulesa.askawi017@gmail.com]

\begin{abstract}
Description of Anxiety in Facing the OSCE UKMPPD Exam in First Taker Student Professional Education Doctors Malahayati University Batch November 2019. Anxiety is a state of excessive tension characterized by feelings of worry, uncertainty, or fear. Anxiety is often experienced by students, especially medical students who will carry out the Competence test as Doctor Profession Program (UKMPPD) including the Objective Structured Clinical Examination (OSCE) and Computer Based Test (CBT) exams. OSCE is a clinical skill assessment instruments in medical students. Anxiety when reaching severe levels of anxiety that would interfere with the course of the test and also may affect the test results on the professional program student doctors who carry it out. Type of research is an descriptive method with cross sectional approach. the aim is to find out how the anxiety in facing the OSCE UKMPPD exam in the first taker student medical education at Malahayati University Batch November 2019. The results showed the highest anxiety is equal to $78(56 \%)$ in mild anxiety. The age distribution that mostly took the OSCE UKMPPD exam was 24 years old, 88 participants $(63.8 \%)$. The most gender distribution was female as many as 99 participants $(71.7 \%)$. The most study period distribution of OSCE UKMPPD participants is the 6-year study period, which is 108 participants $(78.26 \%)$. Based on the most data distribution to illustrate anxiety in facing the OSCE UKMPPD exam in the first taker of medical profession education at the University of Malahayati Bandar Lampung in 2019 was mild anxiety, age 24 years, female sex, and with a study period of 6 years.
\end{abstract}

\section{Keyword : Anxiety, OSCE Exam}

\begin{abstract}
Abstrak : Gambaran Kecemasan Dalam Menghadapi Ujian Osce Ukmppd Pada Mahasiswa First Taker Pendidikan Profesi Dokter Universitas Malahayati Batch November 2019. Kecemasan adalah keadaan tegang berlebihan ditandai perasaan khawatir, tidak menentu, atau takut. Kecemasan sering di alami pada mahasiswa khususnya mahasiswa kedokteran yang akan melaksanakan Ujian Kompetensi Mahasiswa Program Profesi Dokter (UKMPPD) diantaranya ujian Objective Structured Clinical Examination (OSCE) dan Computer Based Test (CBT). OSCE merupakan instrumen penilaian keterampilan klinik pada mahasiswa kedokteran. Kecemasan apabila sudah mencapai tingkat kecemasan yang berat akan mengganggu proses jalannya ujian dan juga memungkinkan mempengaruhi hasil ujian pada mahasiswa program profesi dokter yang melaksanakannya. Jenis penelitian yang digunakan adalah deskriptif dengan menggunakan pendekatan cross sectional. Tujuannya untuk mengetahui gambaran kecemasan dalam menghadapi OSCE UKMPPD pada mahasiswa first taker pendidikan profesi dokter di Universitas Malahayati tahun 2019. Hasil penelitian didapatkan kecemasan paling tinggi yaitu sebesar 78 (56\%) pada kecemasan ringan. Distribusi usia paling banyak mengikuti ujian OSCE UKMPPD adalah usia 24 tahun 88 peserta $(63,8 \%)$. Ditribusi jenis kelamin paling banyak berjenis kelamin perempuan sebanyak 99 peserta $(71,7 \%)$. Distribusi masa studi paling banyak dari peserta OSCE UKMPPD yaitu Masa studi 6 tahun yaitu sebanyak 108 peserta $(78,26 \%)$. Berdasarkan distribusi data terbanyak untuk gambaran kecemasan dalam menghadapi ujian OSCE UKMPPD pada mahasiswa first taker pendidikan
\end{abstract}


profesi dokter di Universitas Malahayati Bandar Lampung tahun 2019 adalah kecemasan ringan, usia 24 tahun, jenis kelamin perempuan, dan dengan masa studi 6 tahun.

\section{Kata Kunci : Kecemasan, Ujian OSCE}

\section{PENDAHULUAN}

Kecemasan merupakan pengalaman perasaan tidak menyenangkan. Kecemasan timbul dari reaksi ketegangan-ketegangan atau dari sistem dalam tubuh, ketegangan ini akibat suatu dorongan dari dalam atau dari luar dan dikuasai oleh susunan urat saraf yang otonom. Orang yang dilanda kecemasan bisa mengganggu keseimbangan pribadi seperti tegang, resah, gelisah, takut, gugup, berkeringat, dan sebagainya. Kecemasan dapat dikategorikan dari tingkat yang sangat rendah sampai dengan tingkat tertinggi (Yuhelrida et al, 2016).

Indonesia merupakan negara dimana setiap tahunnya angka kecemasan semakin meningkat, kecemasan diperkirakan $20 \%$ dari populasi dunia dan sebanyak $47,7 \%$ remaja merasa cemas (Yuhelrida et al, 2016).

Uji Kompetensi Mahasiswa Program Profesi Dokter (UKMPPD), merupakan suatu exit exam yang berskala nasional bagi mahasiswa program profesi dokter sebelum mengangkat sumpah sebagai dokter. Posisi UKMPPD sebagai exit exam dapat menjadi sumber kecemasan bagi mahasiswa. Uji kompetensi ini terdiri dari 2 jenis uji, yaitu pilihan jamak/multiple choice question (MCQ) menggunakan komputer (Computer

Based Test/CBT) dan uji keterampilan pemeriksaan klinis (Objective StructuredClinical Examination/OSCE) (Limen $\mathrm{G}$ et al, 2018). UKMPPD dilakukan diakhir masa studi tahap kepaniteraan klinik untuk mendapatkan sertifikat profesi dari perguruan tinggi, dan sertifikat kompetensi dari Organisasi Profesi setelah Iulus uji (Kesuma, 2017).

Objective Structured Clinical Examination (OSCE) adalah suatu metode untuk menguji kompetensi klinik secara objektif dan terstruktur dalam bentuk putaran station dengan waktu yang telah ditentukan. Seluruh peserta yang melaksanakan OSCE dalam ruangan terdapat soal yang menginstruksikan hal yang harus dilakukan oleh peserta ujian OSCE. Pelaksanaan OSCE ini menuntut mahasiswa untuk mempraktikkan kemampuan yang telah dipelajari di kampus dan di kelompok belajarnya (Mailina WR et al, 2015).

Mahasiswa yang mengikuti UKMPPD terdiri dari peserta yang pertama kali mengikuti (first taker) dan peserta yang sebelumnya telah mengikuti UKMPPD (retaker). Dan pada umumnya peserta yang pertama kali mengikuti UKMPPD (first taker) mengalami kecemasan yang berat. Peserta yang sebelumnya telah mengikuti UKMPPD (retaker) mengalami kecemasan sedang pada periode pertama dan mengalami kecemasan normal pada periode kedua. Berdasarkan penelitian yang ada sebelumnya melalui wawancara, kecemasan yang timbul pada mahasiswa first taker karena merasa belum siap untuk menghadapi UKMPPD, sedangkan pada mahasiswa yang retaker karena peserta takut mengulang kegagalan yang sudah pernah terjadi sebelumnya (Kesuma, 2017). Namun berdasarkan hasil penelitian lain pada umumnya mahasiswa yang mengikuti UKMPPD mengalami kecemasan ringan. Keadaan ini bisa disebabkan oleh beberapa faktor, diantaranya faktor-faktor yang cukup berperan yaitu, jenis kelamin, usia, agama, kali keikutsertaan dalam UKMPPD dan keikutsertaan dalam bimbingan belajar UKMPPD di luar kampus (Wardhana \& Westa, 2015).

Peserta yang dinyatakan lulus akan diberi sertifikat profesi oleh perguruan tinggi dan sertifikat kompetensi oleh organisasi profesi. Dan untuk peserta kompetensi yang tidak lulus dapat mengikuti ujian kompetensi pada periode berikutnya hingga batas masa studi yang dibolehkan sesuai dengan ketentuan peraturan perundang-undangan dan mendapatkan program pembimbingan yang menjadi tanggung jawab fakultas masing-masing (Permenristekdikti, 2016).

Penelitian yang dilakukan oleh Yuhelrida pada tahun 2016 di Fakultas Kedokteran Gigi Universitas Syiah Kuala, menunjukkan tingkat kecemasan mahasiswa dalam menghadapi Objective Structured Clinical Examination (OSCE) sebanyak 5 orang tidak mengalami kecemasan $(17,9 \%)$, 6 orang mengalami kecemasan ringan $(21,4 \%), 6$ orang 
mengalami kecemasan sedang $(21,4 \%)$, 10 orang mengalami kecemasan berat $(35,7 \%)$ dan 1 orang mengalami kecemasan berat sekali $(3,6 \%)$. Kecemasan yang timbul ketika menghadapi ujian akan mempengaruhi performa mahasiswa yaitu mereka dengan tingkat kecemasan yang lebih rendah memberikan performa yang lebih baik dibanding mereka yang mengalami kecemasan sedang dan tinggi (Yuhelrida et al, 2016).

\section{METODE}

Jenis penelitian yang digunakan dalam penelitian ini adalah deskriptif dengan menggunakan pendekatan cross sectional. Tujuannya adalah untuk mengetahui gambaran kecemasan dalam menghadapi OSCE UKMPPD pada mahasiswa first taker pendidikan profesi dokter di Universitas Malahayati Batch November tahun 2019.

Kriteria Inklusi pada penelitian ini yaitu peserta first traker yang bersedia menjadi responden dan peserta yang mengikuti OSCE UKMPPD di Fakultas Kedokteran Universitas Malahayati. Sedangkan kriteria eksklusi yaitu Peserta yang sakit atau dalam masa pengobatan, peserta yang bukan mahasiswa Fakultas Kedokteran Universitas Malahayati, peserta yang tidak bersedia menjadi responden, dan peserta yang mengisi data tidak lengkap.

\section{HASIL}

\section{Usia}

Tabel 1. istribusi Frekuensi Karakteristik Usia peserta first taker

\begin{tabular}{lcc}
\hline Usia & Frekuensi & Persentase(\%) \\
\hline 22 Tahun & 1 & 0,7 \\
23 Tahun & 20 & 14,5 \\
24 Tahun & 88 & 63,8 \\
25 Tahun & 20 & 14,5 \\
26 Tahun & 4 & 2,9 \\
27 Tahun & 1 & 0,7 \\
28 Tahun & 4 & 2,9 \\
\hline Jumlah & 138 & 100 \\
\hline
\end{tabular}

Berdasarkan Tabel 1 di atas didapatkan bahwa sebagian besar peserta adalah usia 24 tahun dengan jumlah 88 peserta $(63,8 \%)$.

\section{Jenis kelamin}

Tabel 2. Distribusi Frekuensi Karakteristik Jenis kelamin peserta first taker

\begin{tabular}{lcc}
\hline Jenis kelamin & Frekuensi & presentase (\%) \\
\hline Perempuan & 99 & 71,7 \\
Laki-laki & 39 & 28,3 \\
\hline Jumlah & 138 & 100 \\
\hline
\end{tabular}

Berdasarkan Tabel 2 dapat perempuan sebanyak 99 peserta $(71,7 \%)$. diketahui bahwa sebagian besar peserta adalah jenis kelamin 


\section{Masa studi}

Tabel 3. Distribusi Frekuensi Karakteristik Masa studi peserta first taker

\begin{tabular}{lcc}
\hline Masa studi & Frekuensi & persentase(\%) \\
\hline 5 tahun 2 bulan & 14 & 10,1 \\
5 tahun 8 bulan & 12 & 8,7 \\
6 tahun & 108 & 78,3 \\
7 tahun & 4 & 2,9 \\
\hline Jumlah & 138 & 100 \\
\hline
\end{tabular}

Berdasarkan Tabel 3 di atas didapatkan bahwa sebagian besar sebanyak 108 peserta $(78,26 \%)$.

\section{Distribusi frekuensi Tingkat kecemasan peserta first taker}

Tabel 4. Distribusi frekuensi Tingkat kecemasan peserta first taker

\begin{tabular}{lcc}
\hline Tingkat kecemasan & Frekuensi & persentase(\%) \\
\hline Tidak cemas & 1 & 0,7 \\
Ringan & 78 & 56,5 \\
Sedang & 59 & 42,8 \\
Berat & 0 & 0 \\
\hline Jumlah & 138 & 100 \\
\hline
\end{tabular}

Berdasarkan tabel 4 diketahui bahwa tingkat kecemasan pada paling tinggi dari peserta adalah kecemasan ringan yaitu sebesar $78 \quad(56,5 \%)$ peserta mengalami kecemasan ringan.

Tabel 5. Distribusi Frekuensi karakteristik Usia Terhadap Tingkat Kecemasan.

\begin{tabular}{|c|c|c|c|c|c|c|c|c|}
\hline \multirow[t]{2}{*}{ Usia/Tahun } & \multicolumn{2}{|c|}{$\begin{array}{c}\text { Tidak } \\
\text { cemas }\end{array}$} & \multicolumn{2}{|c|}{ Ringan } & \multicolumn{2}{|c|}{ Sedang } & \multicolumn{2}{|c|}{ Total } \\
\hline & $\mathbf{F}$ & $\%$ & $\bar{F}$ & $\%$ & $\bar{F}$ & $\%$ & $\bar{F}$ & $\%$ \\
\hline 22 & - & - & - & - & 1 & 100 & 1 & 100 \\
\hline 23 & - & - & 14 & 70 & 6 & 30 & 20 & 100 \\
\hline 24 & - & - & 48 & 54,5 & 40 & 45,4 & 88 & 100 \\
\hline 25 & 1 & 5 & 10 & 50 & 9 & 45 & 20 & 100 \\
\hline 26 & - & - & 4 & 100 & - & - & 4 & 100 \\
\hline 27 & - & - & - & - & 1 & 100 & 1 & 100 \\
\hline 28 & - & - & 2 & 50 & 2 & 50 & 4 & 100 \\
\hline Total & 1 & 0,72 & 78 & 56,5 & 59 & 42,8 & 138 & 100 \\
\hline
\end{tabular}

Berdasarkan tabel 5 diketahui distribusi frekuensi usia terhadap tingkat kecemasan menunjukkan bahwa dari 138 peserta, kecemasan tertinggi adalah usia 24 tahun dengan jumlah 88 peserta yang terdiri dari $48(54,5 \%)$ peserta mengalami kecemasan ringan dan 40(45,5\%) peserta mengalami kecemasan sedang. 
Tabel 6. Distribusi Frekuensi Karakteritik Jenis Kelamin Terhadap Tingkat kecemasan.

\begin{tabular}{lcccccccc}
\hline Jenis kelamin & \multicolumn{2}{l}{ Tidak cemas } & \multicolumn{2}{l}{ Ringan } & \multicolumn{3}{c}{ Sedang } & Total \\
\cline { 2 - 9 } & $\mathbf{F}$ & $\mathbf{\%}$ & $\mathbf{F}$ & $\mathbf{\%}$ & $\mathbf{F}$ & $\mathbf{\%}$ & $\mathbf{F}$ & \% \\
\hline Perempuan & - & - & 52 & 52,5 & 47 & 47,5 & 99 & 100 \\
Laki-laki & 1 & 2,6 & 26 & 66,6 & 12 & 30,8 & 39 & 100 \\
\hline Total & 1 & 0,72 & 78 & 56,6 & 59 & 42,8 & 138 & 100 \\
\hline
\end{tabular}

Berdasarkan tabel 6 Distribusi Frekuensi Karakteritik Jenis Kelamin Terhadap Tingkat kecemasan dari peserta menunjukkan bahwa dari 138 peserta yang paling banyak adalah jenis kelamin perempuan berjumlah 99 peserta dengan 52(52,5\%) peserta mengalami kecemasan ringan dan $47(47,5 \%)$ peserta mengalami kecemasan sedang.

Tabel 7. Distribusi Frekuensi Masa Studi Terhadap Tingkat Kecemasan

\begin{tabular}{ccccccccc}
\hline Masa studi & \multicolumn{2}{c}{$\begin{array}{c}\text { Tidak } \\
\text { cemas }\end{array}$} & \multicolumn{2}{c}{ Ringan } & \multicolumn{2}{c}{ Sedang } & \multicolumn{2}{c}{ Total } \\
\cline { 2 - 9 } & F & $\mathbf{\%}$ & F & $\mathbf{\%}$ & $\mathbf{F}$ & $\mathbf{\%}$ & $\mathbf{F}$ & $\%$ \\
\hline 5 tahun 2 bulan & - & - & 11 & 78,6 & 3 & 21,4 & 14 & 100 \\
5 tahun 8 bulan & - & - & 7 & 58,3 & 5 & 41,7 & 12 & 100 \\
6 tahun & 1 & 0,9 & 58 & 53,7 & 49 & 45,4 & 108 & 100 \\
7 tahun & - & - & 2 & 50 & 2 & 50 & 4 & 100 \\
\hline Total & 1 & 0,72 & 78 & 56,6 & 59 & 42,8 & 138 & 100 \\
\hline
\end{tabular}

Berdasarkan tabel 7 diketahui distribusi frekuensi kecemasan terhadap masa studi dari peserta menunjukkan bahwa dari 138 responden diketahui masa studi paling tinggi mengalami kecemasan adalah masa studi 6 tahun dengan jumlah 108 peserta yang terdiri dari $58(53 \%)$ peserta mengalami kecemasan ringan dan 49(45,4\%) peserta mengalami kecemasan sedang.

\section{PEMBAHASAN}

Hasil penelitian menunjukkan bahwa usia paling banyak mengikuti OSCE UKMPPD di Universitas Malahayati Batch November 2019 adalah usia 24 tahun yaitu sebanyak 88 peserta $(63,76 \%)$, untuk usia paling sedikit mengikuti OSCE UKMPPD adalah usia 22 tahun 1 peserta $(0,72 \%)$, dan usia 27 tahun 1 peserta $(0,72 \%)$. Hal ini terjadi dikarenakan faktor waktu masuknya mahasiswa di Fakultas Kedokteran Universitas Malahayati, mayoritas yang mengikuti ujian OSCE UKMPPD Batch November 2019 adalah angkatan 2013, dan adanya faktor masa studi mahasiswa.

Hasil distribusi karakteristik usia terhadap kecemasan didapatkan tingkat kecemasan paling tinggi terdapat pada usia yang lebih muda yaitu usia 24 tahun berjumlah 88 peserta yang terdiri dari $48(54,5 \%)$ peserta mengalami kecemasan ringan dan $40(45,4 \%)$ peserta mengalami kecemasan sedang, usia 23 tahun dengan jumlah 20 peserta yang terdiri dari $14(70 \%)$ peserta mengalami kecemasan ringan dan $6(30 \%)$ peserta mengalami kecemasan sedang, usia 25 tahu dengan jumlah 20 peserta yang terdiri dari $1(5 \%)$ peserta tidak mengalami kecemasan, $10(50 \%)$ peserta mengalami kecemasan 
ringan, dan 9(45\%) peserta mengalami kecemasan sedang. Artinya peserta yang mempunyai umur lebih muda mempunyai resiko lebih besar untuk mengalami kecemasan dibandingkan peserta yang mempunyai umur lebih tua.

Penelitian ini sejalan dengan penelitian yang dilakukan oleh Kesuma pada tahun 2017 yang diketahui rentang usia mahasiswa adalah 23 tahun sampai dengan 30 tahun dengan presentase terbanyak mahasiswa yang berusia 24 tahun. Usia merupakan salah satu faktor yang berpengaruh terhadap kecemasan, karena usia mempengaruhi psikologi seseorang, semakin tinggi usia semakin baik tingkat kematangan emosi seseorang serta kemampuan dalam menghadapi berbagai persoalan (Kesuma, 2017).

Hasil penelitian ini sesuai dengan teori yang menyatakan pada usia yang semakin tua maka seseorang semakin banyak pengalamannya sehingga pengetahuannya semakin bertambah. Pengetahuan tersebut dapat mengurangi kecemasan (Stuart dan Sundeen, 2007). Senada dengan teori tersebut yang mengungkapkan bahwa seseorang yang berumur lebih muda ternyata lebih mudah mengalami gangguan kecemasan dari pada seseorang yang lebih tua. Semakin meningkat usia maka semakin baik tingkat kematangan seseorang, sehingga lebih mudah dalam mengatasi kecemasan sedangkan orang yang lebih muda kematangan belum tercapai, sehingga lebih mudah mengalami kecemasan (Untari, 2014).

Distribusi frekuensi karakteristik berdasarkan jenis kelamin pada penelitian ini didapatkan hasil pada responden berjenis kelamin perempuan lebih tinggi yaitu sebanyak 99 peserta $(71,7 \%)$. Hal ini bisa disebabkan oleh faktor jumlah masuknya mahasiswa di Fakultas Kedokteran Universitas Malahayati pada tahun 2013 ke bawah lebih banyak perempuan dibandingkan dengan laki-laki. Diketahui mayoritas yang mengikuti ujian OSCE UKMPPD di Fakultas Kedokteran Universitas Malahayati Batch November 2019 adalah angkatan 2013. Dari hasil Distribusi Karakteristik jenis kelamin terhadap kecemasan didapatkan tingkat kecemasan paling tinggi pada perempuan berjumlah 99 peserta dengan 52(52,5\%) peserta mengalami kecemasan ringan dan $47(47,5 \%)$ peserta mengalami kecemasan sedang.
Penelitian ini sejalan dengan penelitian sebelumnya yang dilakukan oleh Yuhelrida pada tahun 2016 yang menyebutkan bahwa perempuan lebih cemas dibandingkan dengan laki-laki, karena laki-laki lebih aktif dan eksploratif, sedangkan perempuan lebih sensitif dalam mempergunakan perasaannya (Yulhelrida, 2016). Terdapat penelitian lainnya yang juga menyebutkan bahwa mahasiswa yang berjenis kelamin perempuan lebih rentan mengalami perubahan emosional karena memiliki perbedaan hormonal, rendahnya tingkat percaya diri, dan tingginya ekspektasi atau harapan akan hasil ujiannya dibandingkan dengan mahasiswa yang berjenis kelamin laki-laki (Kesuma, 2017).

Hasil penelitian ini sesuai dengan teori yang diungkapkan oleh Untari bahwa kecemasan lebih sering dialami wanita dibanding dengan pria. Perempuan memiliki tingkat kecemasan yang lebih tinggi dibandingkan dengan laki-laki. Dikarenakan perempuan lebih peka terhadap emosinya yang pada akhirnya peka juga terhadap perasaan cemasnya (Untari, 2014). Dan teori tersebut sejalan dengan teori Stuart dan Sundeen yang menyatakan bahwa perempuan lebih cemas akan ketidakmampuannya dibanding dengan laki-laki. Laki-laki lebih aktif, eksploratif, sedangkan perempuan lebih sensitif. Kemudian penelitian lain juga menunjukkan bahwa laki- laki lebih rileks dibanding perempuan (Stuart dan Sundeen tahun, 2007).

Masa studi peserta OSCE yang berbeda-beda bisa disebabkan karena peserta yang menyelesaikan masa studinya lebih cepat atau lebih lama, hal tersebut bisa terjadi oleh beberapa faktor diantaranya peserta ada yang mengambil cuti, mengulang kuliah dikarenakan nilai yang kurang, dan faktor-faktor lain pada saat masa studinya. Dari hasil penelitian didapatkan masa studi yang paling tinggi mengikuti ujian OSCE UKMPPD adalah masa studi 6 tahun yaitu, sebanyak 108 peserta $(78,26 \%)$ karena diketahui dari data peserta pada ujian OSCE UKMPPD Tahun 2019 mayoritas adalah angkatan 2013 dimana normalnya masa studi dari masa preklinik sampai dengan klinik membutuhkan waktu maksimal 6 tahun. Dari Ditribusi Frekuensi masa studi terhadap kecemasan didapatkan masa studi paling tinggi tingkat kecemasannya adalah masa studi 6 tahun dengan total 108 peserta yang terdiri dari $1(0,9 \%)$ 
peserta tidak mengalami kecemasan, $58(53,7 \%)$ peserta mengalami kecemasan ringan dan $49(45,4 \%)$ peserta mengalami kecemasan sedang. Hal ini dapat terjadi karena beberapa faktor salah satunya adalah takutnya mahasiswa akan hasil yang tidak memuaskan atau tidak lulus dan dapat menyebabkan lebih lama lagi untuk mendapatkan gelar dokter.

Menurut penelitian yang dilakukan oleh Anissa tahun 2018 yang menyatakan bahwa semakin tinggi masa studi mahasiswa maka kecemasan mahasiswa dalam menghadapi ujian semakin ringan. Dan menurut Afzal et all (2012) dalam penelitiannya menunjukan prevalensi kecemasan lebih tinggi dirasakan pada mahasiswa dengan masa studi tahun pertama dan kedua. Mahasiswa yang telah menempuh masa studi lebih lama akan mampu beradaptasi dengan keadaan yang memicu kecemasan berdasarkan pengalaman-pengalaman yang lebih banyak dalam menghadapi ujian sehingga lebih tahan terhadap tekanan-tekanan dibandingkan mahasiswa pada masa studi tahun pertama (Afzal et all, 2012).

Pada penelitian ini peserta OSCE yang memiliki tingkat kecemasan paling tinggi yaitu sebesar 78 (56\%) pada kecemasan ringan. Ini terjadi disebabkan oleh karena tidak semua peserta OSCE menyatakan bahwa dirinya merasa cemas, sebagian kecil mengaku merasa biasa saja. $\mathrm{Hal}$ ini kemungkinan disebabkan karena peserta telah sering mengikuti OSCE/simulasi OSCE sebelumnya atau akibat sifat kepribadian dari peserta itu sendiri. Semakin sering mengikuti ujian menyebabkan mahasiswa memiliki mekanisme coping yang lebih baik terhadap kecemasan.

Menurut teori kecemasan ringan berhubungan dengan ketegangan dalam kehidupan sehari-hari, kecemasan ini menyebabkan individu menjadi waspada dan meningkatkan lapang presepsinya. Kecemasan ini dapat memotivasi belajar dan menghasilkan pertumbuhan serta kreativitas (Stuart dan Sundeen, 2006).

Mahasiswa dengan tingkat kecemasan yang ringan, performanya akan lebih baik dibanding mahasiswa yang mengalami kecemasan sedang, dan berat. Tingkat kecemasan ringan yang ditimbulkan akan memotivasi mahasiswa lebih bersemangat untuk mempersiapkan diri menghadapi ujian. Mahasiswa dengan motivasi berprestasi yang tinggi dapat menunjukkan perilaku yang berorientasi ke prestasi. Ini terlihat pada saat menghadapi ujian, mereka dapat mengendalikan ketegangan dan tetap tenang (Kesuma, 2017).

Berdasarkan penelitian sebelumnya penelitian ini sejalan dengan penelitian yang dilakukan oleh Clareza Arief Wardhana dan I Wayan Westay yang mengatakan pada umumnya mahasiswa yang mengikuti UKMPPD di Universitas Udayana mengalami kecemasan ringan $(58,6 \%)$. Keadaan ini bisa disebabkan oleh beberapa faktor, diantaranya faktor-faktor yang cukup berperan yang diteliti dalam penelitian ini adalah jenis kelamin,usia, agama, kali keikutsertaan dalam UKMPPD dan keikutsertaan dalam bimbingan belajar UKMPPD di luar kampus (Wardhana dan Wayan, 2015).

Penelitian ini sesuai dengan teori yang disampaikan oleh Fidment (2012) yang menyatakan bahwa persiapan sebelum ujian merupakan kunci strategi coping untuk beradaptasi dengan kecemasan yang dialami. Dalam situasi tertentu, kecemasan dapat menjadi efek yang positif bagi mahasiswa dalam memfokuskan dan menggunakan kemampuan strategi coping untuk memanajemen keadaan yang mereka hadapi sehingga dengan begitu performa mereka akan lebih baik dalam ujian nanti karena telah terbiasa menghadapi kondisi tersebut (Fidment, 2012).

\section{KESIMPULAN}

Berdasarkan hasil pembahasan penelitian, maka dapat diambil kesimpulan mengenai gambaran kecemasan pada peserta first taker ujian OSCE UKMPPD di Fakultas Kedokteran Universitas Malahayati Batch November 2019 sebagai berikut :

1. Distribusi frekuensi Tingkat kecemasan peserta menunjukkan dari 138 responden kecemasan paling tinggi adalah $78(56,5 \%)$ peserta pada tingkat kecemasan ringan.

2. Distribusi Frekuensi Usia peserta menunjukkan usia paling banyak mengikuti OSCE UKMPPD adalah usia 24 tahun yaitu sebanyak $88(63,76 \%)$ peserta yang terdiri dari 48(54,5\%) peserta mengalami kecemasan ringan dan $40(45,4 \%)$ peserta mengalami kecemasan sedang.

3. Distribusi Frekuensi Jenis kelamin menunjukkan jenis kelamin perempuan lebih tinggi yaitu sebanyak 99(71,7\%)peserta yang terdiri dari $52(52,5 \%)$ peserta mengalami 
kecemasan ringan dan $47(47,5 \%)$ peserta mengalami kecemasan sedang.

4. Distribusi Frekuensi Masa studi peserta menunjukkan paling banyak peserta dengan masa studi 6 tahun yaitu 108 peserta $(78,26 \%)$ yang terdiri dari $1(0,9 \%)$ peserta tidak mengalami kecemasan, 58(53,7\%) peserta mengalami kecemasan ringan dan $49(45,4 \%)$ peserta mengalami kecemasan sedang.

\section{SARAN}

Bagi Institusi, Sebagai bahan masukan untuk Universitas Malahayati mengenai pentingnya menanggulangi kecemasan, karena pada peserta yang akan menjalani ujian OSCE masih banyak yang mengalami kecemasan, sehingga

\section{DAFTAR PUSTAKA}

Afzal, H., Afzal, S., Siddique, S. A. (2012). Measure used by medical student to reduce test anxiety. JPMA. The joernal of the pakistan medical Association,62 (9),982-986. https://eu ropepmc.Org Larticle/med/23139995

Anissa, L. M., Suryani, S., \& Mirwanti, R. (2018). Tingkat kecemasan mahasiswa keperawatan dalam menghadapi ujian berbasis computer based test. Fakultas Keperawatan Universitas Padjadjaran Bandung: JawaBarat.http://jurnalnasio nal.Ump.ac.id/index.php/medisains/art icle/view/2522

Fidment,S. (2012). The Objective Structured Clinical Exam (OSCE): A Qualitative Study Exploring the Heathcare Student's Experience. Student Engangemen and Experience Jurnal.

https://journals.shu.ac.uk/index.php/s ee

Kesuma, S. K. (2017). Gambaran Tingkat Kecemasan Mahasiswa Kedokteran yang Mengikuti Uji Kompetensi Mahasiswa Program Profesi Dokter di Fakultas Kedokteran Tanjungpura Tahun 2017. Jurnal Mahasiswa PSPD FK Universitas Tanjung pura:Pontianak.

http://jurnal.untan.ac.id/index.php/jfk Larti cle/viewFile /32174/75676580685

Mailina, W. R., Zulharman., \& Asri, E. (2016). Hubungan efikasi diri dengan nilai objective structured clinical examination (OSCE) pada Mahasiswa tahun ketiga Fakultas Kedokteran Universitas Riau. JOM FK Volume 2: disarankan perlu diadakannya kerjasama antara Prodi Profesi Kedokteran selaku pelaksana OSCE UKMPPD dengan Prodi Psikologi untuk mendapatkan motivasi agar pada saat pelaksanaan ujian dapat mengurangi kecemasan pada mahasiswa, karena kecemasan dapat menggangu konsentrasi para peserta ujian sehingga memungkinkan mempengaruhi hasil ujian tersebut. Bagi peneliti selanjutnya yang tertarik untuk meneliti tingkat kecemasan OSCE disarankan untuk meneliti kecemasan ujian CBT juga agar dapat membandingkan tingkat kecemasan antara peserta OSCE dan CBT.

Pekanbaru.https://jom.unri.ac.id/index .php/JOMFDOK/ article /view /64 50/0

Permenristekdikti. (2016). Peraturan menteri riset, teknologi, dan pendidikan tinggi republik indonesia tentang tata cara pelaksanaan uji pelaksaan uji kompetensi mahasiswa profesi dokter atau dokter gigi.http://aktivasi.Pnuk

mppd.ristekdikti.go.id/berita/11-PERM ENRISTEK-NO-18-TAHUN-2015

Stuart, G.W. \& Sundeen, S.J. (2006). Buku Saku Keperawatan Jiwa. Ed 5. Penerbit Buku Kedokteran EGC. Jakarta.

Stuart, \& Sundeen. (2007). Buku Saku Keperawatan Jiwa Edisi 4. Jakarta : EGC

Untari, I \& Rohmawati. (2014). Faktor-Faktor yang Mempengaruhi Kecemasan pada Usia Pertengahan dalam Menghadapi Proses Menua (Aging Process). Universitas Muhammadiyah Semarang :Semarang.http://jurnal.akper17.ac.id /index.php/JK17/article/view/9/13

Wardhana, C.A \& Westa I.W. (2015). Prevalensi Cemas Pada Mahasiswa Kedokteran yang Mengikuti Uji Kompetensi Mahasiswa Program Profesi Dokter di Fakultas Kedokteran Universitas Udayana : Denpasar. D:/JU RNAL\%20SKRIPSI/UDAYANA\%20FIRS T\%20TAKER.pdf

Yuhelrida, Andriani, P. \& Aya, P.S. (2016). Tingkat Kecemasan Dalam Menghadapi Objective Structured Clinical Examination (OSCE) (Studi pada Peserta UKMP2DG Unsyiah Periode II Tahun 2016). Universitas Syiah Kuala: 
Banda Aceh. http://etd.unsyiah.ac.id/i

ndex.php? $=$ show detail\&id $=24659$ 